\title{
Good Transboundary Water Governance in the 2015 Sustainable Development Goals: A Legal Perspective
}

\author{
Mallory Orme, LLM candidate 2015, University of Strathclyde Law School, Glasgow, \\ Scotland, UK (mallory.orme.2014@uni.strath.ac.uk) \\ Zoë Cuthbert , LLM candidate 2015, University of Strathclyde Law School, Glasgow, \\ Scotland, UK (zoe.cuthbert.2014@uni.strath.ac.uk) \\ Francesco Sindico, Director, Strathclyde Centre for Environmental Law and \\ Governance and Reader in International Environmental Law, University of \\ Strathclyde Law School, Glasgow, Scotland, UK \\ (Francesco.sindico@strath.ac.uk) (corresponding author) \\ Julie Gibson, LLM candidate 2015, University of Strathclyde Law School, Glasgow, \\ Scotland, UK (julie.gibson.2014@uni.strath.ac.uk) \\ Renice Bostic, LLM candidate 2015, University of Strathclyde Law School, Glasgow, \\ Scotland, UK (renice.bostic.2014@uni.strath.ac.uk)
}

\begin{abstract}
The goal of this paper is to discuss whether the Sustainable Development Goals (SDGs) address the cooperation necessary to facilitate a system of transboundary water governance. To do so we developed a Matrix of Good Transboundary Water Governance. We conclude that transboundary water governance requires a holistic interpretation and implementation of the SDGs understood as a whole. In particular, good governance and, ultimately, sustainable development require stakeholders to focus not only on the water SDG (SDG 6), but also on SDG 16, which focuses on international cooperation.
\end{abstract}

Keywords:

Sustainable Development Goals; transboundary water governance; law; international cooperation

\section{Introduction}

Sustainable development is currently at the forefront of the global agenda with the international community posed to adopt the post-2015 Sustainable Development Goals (SDGs) in September 2015. Considering the increased stress on water sources caused by population growth, 
climate change, pollution and many other factors, the establishment of good water governance is crucial for nations to be able to create effective strategies for sustainable development. Considering the staggering number of riparian states and the amount of shared watercourses and transboundary aquifers, ${ }^{1}$ it is critical to include transboundary water governance in any discussion on good water governance. In fact, while good water governance is undoubtedly important, there needs to be a better system in place for the unique considerations and priorities of nations, which share watercourses and aquifers.

Against this background, the goal of this paper is to discuss whether the SDGs address the cooperation necessary to facilitate a system of transboundary water governance, and to do so we used a Matrix of Good Transboundary Water Governance. From the start we acknowledge that water governance is a multifaceted and multidisciplinary concept. However, in this paper we will look at it mainly through the lens of international law. The article is divided in three main sections, which follow this introduction. Section II takes the reader from the Millennium Development Goals (MDGs) to the SDGs. Section III follows on by providing a further justification as to why we need to look also at transboundary water governance, and not only at good water governance. It is in this part of the paper that we present and explain the Matrix of Good Transboundary Water Governance, which stems from the combination of key primary and secondary international water law sources. Section IV undertakes a critical assessment of transboundary water governance within the SDGs, looking at both sector specific SDGs and cross cutting SDGs.

The article concludes that future transboundary water governance requires a holistic interpretation and implementation of the SDGs understood as a whole. If stakeholders were to focus only on the water SDG (SDG 6) this would be counterproductive. Firstly, because water is present in many of the others sectors touched by other SDGs. Secondly, and more importantly for the purposes of this paper, because many of the criteria and obligations present in the Matrix of Good Transboundary Water Governance will be met only if careful attention is given to SDG 16, which focuses on international cooperation as a means to promote good governance and, ultimately, 
sustainable development. Fully aware that the SDG process is still an open one, and that the list of SDGs and targets may well be (slightly) amended at the last negotiating session in New York before the United Nations (UN) General Assembly in September 2015, the points raised in this article (based on the study of the SDG process in the run up to its finalisation) can still be relevant in addressing the inter-linkage between sustainable development and transboundary water governance.

\section{From the MDGs to the SDGs}

In 2000 the UN launched a framework for global action to tackle poverty reduction in developing countries: the Millennium Development Goals (MDGs). The MDGs mark a historic and effective method of global mobilisation to achieve a set of important social priorities worldwide (Sachs, 2012: 2206). For more than a decade, the MDGs have remained a focus of global policy debates and national policy planning. There is widespread feeling amongst policy makers that progress against poverty, hunger and disease is notable and that the MDGs have played an important role in securing that progress (Sachs, 2012: 2206). It has been globally agreed that goals to fight poverty should continue beyond 2015, when the MDGs are set to expire at the end of the year. With the need to define a replacement framework for the MDGs, the post-2015 development agenda has been formally on-going since the Rio+20 Conference in June 2012 (UN DESA, 2015) when the international community agreed to launch a process to develop a set of Sustainable Development Goals (Chasek et al, 2015). The UN has emphasised that while aiming to complete the unfinished MDG agenda, the SDGs will be of relevance for all UN Member countries in the world (UN Water, 2014). The SDGs map out a universal agenda to cover all three dimensions of sustainable development (the economic, social and environmental aspects), aiming to address the many interlinked challenges our world is facing (Schmidt-Traub and Sachs, 2015: 30). The agenda will apply to both developed and developing countries driven by the "leave no-one behind" principle. Over the last two years a global consultation process has taken place, encompassing the UN, national governments, civil society, academics and businesses, partnered with the formal UN process of debate and negotiation to develop a new 
international development framework (NIDOS, 2015). In July 2014, the UN General Assembly Open Working Group (UNGA OWG) proposed a document containing 17 goals and 169 targets on sustainable development. ${ }^{2}$

The MDGs were not a legally binding set of obligations, but rather a set of moral and practical commitments. Likewise, the SDGs are not framed as legally binding obligations, but they still have governing implications. The SDG framework addresses key systemic barriers to sustainable development such as inequality, unsustainable consumption patterns, weak institutional capacity, and environmental degradation that the MDGs neglected (International Council for Science, 2015). To ensure that 'no-one is left behind' States must be able to translate the SDGs into national targets, and develop and implement policies to achieve the SDGs. To deliver on the SDGs countries must engage not just across sectors, but also across borders (Van Der Bliek et al, 2014), which leads us to the next section of this article in which we discuss the need to discuss "transboundary" water governance.

\section{From Good Water Governance to Good Transboundary Water Governance}

\section{Defining Good Water Governance}

In examining the trends in transboundary water governance, it is important to first have a grasp of what water governance means from a legal point of view. There have been numerous definitions put forth to address the multifarious nature of water governance, with relatively little written to distinguish it from governance on local, global and transboundary scales. One such definition states that "Water governance addresses equity and efficiency in resource and services allocation and distribution, water administration, the balancing of use between economic and ecosystem needs, policies, legislation and institutions, as well as the clarification of the roles of government, civil society and the private sector." (Grigg, 2011). While this explanation provides insight and precision into a complex field, for the purpose of this paper it should be taken a step further in stating that transboundary water governance must also create a system of norms that can be applicable and flexible to the unique conditions of the water-users and regional environment in which it is put into force. It would be nearly impossible to delineate a precise definition which is able to 
include all of the different purposes and methods of water governance; what can be understood is that transboundary water governance is characterised also by certain legal criteria and obligations which can change or expand depending on the context in which it operates. We are aware that transboundary water governance implies inputs from many other disciplines, and not only from law (Mirumachi, 2015; Blatter, 2000). We are also well aware that transboundary water governance can rely heavily on informal approaches, which are not based on inter-governmental institutions and are more dependent on regional approaches (Conca, 2012). Some authors have also explored the role of role of leadership, representativeness, legitimacy, and comprehensiveness in global environmental policy formulation and implementation (Pahl-Wostl and others, 2013). Others have analysed the links between integrated water resource management and hydrosolidarity through the lens of equity and ethics (Gerlak and others, 2011). Finally, leading studies in global environmental governance have raised concerns about putting too much emphasis on the format of water governance, without enough attention on the functions that such a governance scheme would be asked to deal with (Young, 2008). The same author has explored questions of fit, interplay and scale in determining effective international regimes, which are of interest also to transboundary water governance (Young, 2003).

However, as stated in the introduction, in this paper we focus our attention on the legal side of transboundary water governance and in this context there are two global legal frameworks to consider when analysing transboundary water governance. The first one is the United Nations Watercourses Convention (UNWC) adopted in 1997 and entered into force in 2014. This landmark global convention was aimed to create a system of comprehensive governance to address some of the particular challenges of the many countries who share water resources. ${ }^{3}$ Ratification of the treaty was a painstakingly slow progress, and as of 2014, there are only 35 parties to the treaty, with many reluctant to ratify it due to political and economic concerns, or a lack of relevance for countries' individual interests (Salman, 2007: 13). Additionally, there are concerns that interpretation of the UNWC is too difficult, due to the use of contradictory language and conflicting interests, with some of its provisions directly in conflict with other provisions (Rieu-Clarke and Loures, 2009). Many of these concerns have been addressed as being nothing more than inaccurate interpretations and 
misconceptions of the Convention (Salman, 2007: 14). Indisputably, the UNWC has championed the cause of good governance for transboundary water sources and has established some of the most important components to achieve this.

A second legal framework to consider in transboundary water governance is the UN International Law Commission Draft Articles on the Law of Transboundary Aquifers (the Draft Articles), adopted in 2008 and which have now been endorsed and annexed by successive UN General Assembly Resolutions, the last one in $2013 .{ }^{4}$ While there have in the past a handful of treaties aimed at the management of specific transboundary aquifers, this was the first legal instrument to cover international law at the global level concerning transboundary aquifers (UN, 2013).

The UNWC and the Draft Articles are not the only significant international legal instruments important for transboundary water governance. There are, especially in the case of surface water, plenty of bilateral and regional instruments and there are surface water and groundwater focused related instruments within the United Nations Economic Commission for Europe (UNECE), which have the potential of global applicability. However, for the purposes of this paper, and in particular for the development of the 'Good Transboundary Water Governance Matrix' we have taken the UNWC and the Draft Articles as the key primary international legal sources relevant for transboundary water governance.

\section{The Good Transboundary Water Governance Matrix}

Good transboundary water governance can be characterised by two sets of criteria: substantive and procedural (McCaffery, 2007). Substantive criteria primarily promote cooperation for joint management, and sustainability for a healthy and renewable environment. Procedural criteria provide for the discharge of these substantive principles in international law by promoting transparency, predictability and accountability. Figure 1 below presents the 'Good Transboundary Water Governance Matrix', developed from an analysis of primary and secondary sources, and summarising the most salient criteria and obligations in transboundary water governance.

[Figure 1 here] 
The purpose of the Good Transboundary Water Governance Matrix is not to provide a comprehensive model of governance (this would require a wider multidisciplinary study), rather to utilise it in assessing the current state of the SDGs in order to determine their role in future transboundary water governance. Substantive and procedural criteria present in the matrix reflect norms and obligations set out by the UNWC and the Draft Articles, some of which have acquired a customary nature under international law. Due to the legal focus posited in this paper, the matrix deliberately leaves out emerging concepts such as water security (Cook and Bakker, 2012), despite acknowledging its importance in a wider multidisciplinary approach to transboundary water governance.

Within the substantive criteria, there are three key legal obligations (See Figure 1). The first of these obligations is to utilise the shared watercourse or the transboundary aquifer in an equitable and reasonable manner. This is the fundamental principle that water-users should be afforded equal access to water, along with the responsibility to be mindful and reasonable users of the shared resource (UNWC, 1997: Article 5; Draft Articles, 2008: Article 4; McCaffery, 2007; McIntyre, 2007). This principle is difficult to pin point as its application will always be based on the context to which it applies and the outcome will depend on a weighing and balancing of specific factors that States need to take into account when utilising the shared resource, which will ultimately define whether the latter has been used in an equitable and reasonable manner (UNWC, 1997: Article 5; Draft Articles, 2008: Article 4; Rieu-Clarke and Loures, 2009). Despite the difficulties in implementing it, the equitable and reasonable utilisation principle is nonetheless widely considered as the cornerstone of international water law, and the foremost concept on which good transboundary water governance should be anchored upon.

The second substantive criterion is the duty not to cause significant harm, derived from the theory of limited territorial sovereignty (UNWC Fact Sheet, 2014: Number 5; UNWC, 1997: Article 7; Draft Articles, 2008: Article 6). This relates to limiting the amount of pollution or overexploitation, especially when it could affect the health and safety of downstream riparians, or the natural 
environment. The duty not to cause significant harm is now considered a customary international law obligation under international law (International Court of Justice, 1996) and can be found enshrined in both the Stockholm Declaration on the Human Environment (UNEP, 1972: Principle 21) and the Rio Declaration on Environment and Development (UNEP, 1992: Principle 2).

The third and final transboundary water governance substantive criterion is to protect and conserve water-related ecosystems. This obligation includes the regulation of floods, erosion, disease, and the need to adopt a precautionary approach (McCaffrey, 2007). In regards to transboundary aquifers, the Draft Articles state the purpose of this as to "ensure that the quality and quantity of water retained in an aquifer as well as that released through its discharge zones, are sufficient to protect and preserve such ecosystems" (Draft Articles, 2008: Article 10). The UN Watercourses Convention lists this obligation as being an extension of the principle of equitable and reasonable use, for the reason that "any activity which threatens the protection and preservation of ecosystems of an international watercourse might potentially be considered inequitable and unreasonable because it threatens the long-term viability of the resource" (UNWC, 1997: Article 20; UNWC Fact Sheet, 2014: Number 7).

Moving now to the procedural criteria of the Good Transboundary Water Matrix, one can find four obligations that promote transparency, accountability and predictability (See figure 1). The first obligation is to notify and exchange information (UNWC, 1997: articles 9 and 12; Draft Articles, 2008: Article 15; Mclntyre, 2010). This is implemented by parties notifying all other parties of information which concerns planned measures, which are likely to have a significant negative impact on other water-users. Planned measures with possible adverse effects must also include in their notification relevant technical data and information. In addition to information exchange regarding planned measures, the criterion reflects the encouragement of peer-to-peer support and information exchange relating to best practices. The duty to notify also includes a reply to notification period in which transboundary parties have an allotted time period to evaluate the possible effects of the project and communicate their own findings. 
The second criterion refers to the obligation to consult the public: i.e. public participation. This should create a forum in which water-users and stakeholders from all countries would be able to express concerns which could then be resolved or translated into policy (UNECE, 1998; Tignino and Sangbana, 2015).

Environmental impact assessment is the third procedural criterion present in the Good Transboundary Water Matrix. The UNWC describes the overall aim of EIA as "to provide a basis by which to come to an informed decision through and thorough analysis of anticipated environmental impacts - revealing the main risks of the project and providing pathways for modifications of the plan to mitigate adverse environmental effects" (UNWC, 1997: Article 12; Draft Articles, 2008: Article 15.2; McIntyre, 2010).

The fourth and final procedural criterion is access to justice, which is a term used to describe access to an administrative and judicial review mechanisms (UNECE, 1998; Bruch, 2002). Information exchange and public participation rely on enforcement and review mechanisms to ensure efficacy and equity. In fact, only if there is an effective access to justice system in place will parties who have not been notified (breach of the duty to notify), or who have not participated in the process (breach of public participation obligation), be able to seek redress (Sanchez and Roberts, 2014: 91).

To sum up, the Good Transboundary Water Governance Matrix provides a legal framework of substantive and procedural criteria that can be used to assess the SDGs to see whether they align themselves to good transboundary water governance. The question becomes whether the SDGs as a whole, or specific relevant SDGs, recognise the importance of these criteria in such a way that effectively promotes cooperation, sustainability, predictability, accountability and transparency in the context of transboundary water governance. This is what the next section of this articles aims to do. 
The SDG process to create universal goals has provided an opportunity for the global community to come together to create a sustainable future in an interconnected world. Water is a key prerequisite for all three dimensions of sustainable development (Gurria, 2009: 396). Good transboundary water governance depends on a number of factors, including strong policy, legal, and regulatory frameworks; more effective implementation organizations; a civic determination to improve water governance; and appropriate investment (Bucknall, 2006: 21). Against this background, in this section of the paper we will first look at whether water has the dedicated space it deserves within the SDGs. We will analyse the so called "Water Goal" (SDG 6) to see whether there are any aspects therein that resonate with the Good Transboundary Water Matrix presented in the previous section. We will then address whether water can be considered to be an essential element of other sectorial SDGs. We will see that there are many draft goals that rely heavily on good water governance. The question, again, will be to discuss whether the substantive and procedural criteria present in the Good Transboundary Water Matrix can be identified in these non-water SDGs. Finally, this section will conclude by looking into the possibility that cross cutting non sectorial SDGs may play a relevant role for the future of transboundary water governance.

\section{Goal 6 - The Water Goal}

A standalone goal on water in the SDGs framework is essential to tackle global water problems across all spheres of human and economic activities, and to meet all other development goals (UNESCO International Hydrological Programme, 2014). Due to the importance that water has for the solution of other global problems, a goal dedicated to water is fundamental to mobilise concrete commitments and concerted action on all water-related issues through a coherent international framework (UNESCO International Hydrological Programme, 2014). A stand-alone goal on water was not a given, despite the fact that already in the Rio+20 UN Conference on Sustainable Development in 2012 water had been recognised as an important and cross-cutting issue (UN General Assembly, 
2012). In the run up to the adoption of the SDGs several statements emerged in favour of providing water the place it deserved within the future framework for sustainable development. One of these was the official statement from the Budapest Water Summit in 2013 that also comprised a political declaration and policy recommendations in support of a stand-alone SDG on water (Budapest Water Summit Statement, 2013). Furthermore, the 2014 World Water Week closed with a call for inclusion of a standalone water target under the post-2015 development agenda (IISD, 2014). These efforts and others finally led to having stand-alone water related SDG, which provides a framework for inter-state management and commitment towards tackling the global water crisis.

But does this water SDG address transboundary water governance? Goal 6 is ambitious, with 8 targets that will be very challenging to implement and achieve, given that they will require major changes in water management among many nations to harmonize governance, data collection and sharing polices and water resources. An analysis of SDG 6 conveys that transboundary water governance is not covered beyond target 6.5 which proposes, "By 2030, implement integrated water resources management (IWRM) at all levels, including through transboundary cooperation as appropriate" (SDG 6). Little as this may seem, the inclusion of a reference to "transboundary cooperation" is relevant. The SDG does not refer to the criteria that promote cooperation and sustainability according to the Good Transboundary Water Matrix (equitable and reasonable utilisation, duty not to cause significant harm and protect and preserve the environment and ecosystems), but that probably was too much of an ask. Still, if to achieve transboundary cooperation States should follow the obligations contained in such criteria, it will be for the implementation of the SDGs to operationalise the call for transboundary cooperation in the context of implementing "IWRM at all levels".

If the water related SDG only provides a very loose link to the substantive criteria present in the Good Transboundary Water Matrix, does a closer look at the other SDGs reveal a stronger presence of substantive and procedural criteria? We will first look at this possibility by looking at SDGs 
that deal with specific sectors, but for which water is highly relevant, before moving to more cross cutting SDGs.

\section{Cross-cutting Sectorial Goals}

Water is vital for all forms of life; it connects ecology, development and society. Water issues are intrinsically linked to other sustainable development issues such as poverty, hunger, health, education, gender inequality, ecosystems integrity, climate change and disasters (UNESCO International Hydrological Programme, 2014). It is not surprising therefore, that while there is one goal dedicated to ensuring the availability and sustainable management of water, a closer analysis of the other sixteen goals and their targets reveals linkages between water and the other SDGs. Goal 6 is linked both directly and indirectly with targets in each of the other SDGs. In particular, there are four proposed SDGs (Goals 3, 11, 12 and 15) that explicitly mention water in one or more of their proposed targets. ${ }^{5}$

Consider SDG 11 and 12 which focus on making cities and human settlements more sustainable, ${ }^{6}$ and ensuring sustainable consumption and production patterns. Both of these goals directly refer to water, namely in reducing the number of water-related disasters (Target 11.5); and reducing the release of chemicals into water (Target 12.4) (SDGs 11 and 12). Another crucial element highlighted in goal 11 is enhancing the resilience of cities and human settlements. Resilience to some of the manifestations of climate change such as heatwaves, drought, famine and desertification for example, cannot be built without the sustainable use and access to water. In this context it is useful to recall target 6.4 that outlines, "By 2030, substantially increase water-use efficiency across all sectors and ensure sustainable withdrawals and supply of freshwater to address water scarcity..." (SDG 6). Implementation of goals 11 and 12 will be increasingly problematic if water management is not effectively addressed in cities and human settlements. Furthermore, if sustainable consumption and production patterns are not implemented appropriately, transboundary water resources will be severely impacted. 
A closer review of all SDGs indicates that the goals and targets that do not explicitly mention water can also be considered to have strong synergies with goal 6 . For example, it will not be possible to end poverty (Goal 1) or achieve most of the other SDGs without significant investments in water (UN DESA, 2015). A further example of how water is crucial to meet sustainable development comes from Goal 2, which is centred on ending hunger, achieving food security and providing sustainable agriculture. Although the targets included in this goal do not specifically mention water, it is particularly relevant as agriculture is a highly intensive water sector and water (both surface and groundwater) plays an important role in sustainably adapting to climate change. Additionally, water can be seen as intrinsic to Goal 2 given the critical role water plays in achieving food security, and the importance of improving agricultural productivity to reduce poverty, which is the overarching aim of the sustainable development agenda (UN DESA, 2015).

Another area in which water is not explicitly mentioned but nonetheless very clearly linked to water is the energy sector. Goal 7 is dedicated to "ensuring access to affordable, reliable, sustainable and modern energy for all". In this context, it is very important to note the existence of hydropower, which has long been debated as a source of sustainable energy. Hydropower currently supplies approximately one-fifth of the world's power generation, and for many countries it is the only domestic energy resource (Kaygusuz, 2009). For this reason, Goal 7 is inherently linked back to the water goal, and target 6.4 on increasing water-use efficiency.

Goal 13 must also be discussed as it is dedicated to taking "urgent action to combat climate and its impacts". This is a critical component of sustainable development as climate change has drastically affected water sources in multiple ways, around the world. Unpredictable rainfall has caused severe flooding, making human settlements vulnerable and desperately in need of adaptive strategies for floodplain management (Burrel, Davar, and Hughes, 2007). Target 13.3 is to "integrate climate change measures into national policies, strategies, and planning". This undoubtedly includes transboundary water governance. While not explicitly referring to them, climate change is an influencing factor in all three substantive criteria listed in the Matrix, including equitable and 
reasonable utilisation, duty not to cause significant harm, and to protect and conserve ecosystems. These principles take on new meaning when water resources become unpredictable, and prone to flooding and droughts. For this reason, Goal 13 is indefinitely linked with Goal 6 on water, and the Good Transboundary Water Governance Matrix.

Finally, Goal 15, which requires to "protect, restore and promote sustainable use of terrestrial ecosystems", is very clearly connected to sustainable water management and the Matrix outlined in this article. This is centrally important to transboundary water governance as international watercourses serve as the habitats for a vast array of species. Target 15.9 precisely coincides with the third principle of substantive criteria, which is to protect and conserve ecosystems. Pollution, climate change, and environmental pressures from population growth are just a few of the challenges in maintaining effective and sustainable transboundary water governance while also protecting ecosystems. For this reason, it is important to integrate the values of conservation and preservation into transboundary development decisions.

Figure 2 below demonstrates the cross-cutting nature of the SDGs by exhibiting the links which can be made between the goals and the substantive and procedural criteria as described in the Matrix. The centre column lists the SDGs which relate to transboundary water governance, and whether that relationship is directly stated or indirectly implied in the actual text of the goals. The substantive and procedural criteria columns on either side list the specific targets (colour-coordinated with their goals for quick reference) that with close analysis can be found to express the criteria and obligations conveyed in the Good Transboundary Water Governance Matrix.

[Figure 2 here]

Considering the sectorial SDGs mentioned in this section, it is evident that to view them in an isolated, individual manner, they would appear to fall short on addressing good transboundary water governance. However, a more in depth analysis illuminates the multitude of linkages between water, sustainability and the substantive criteria found in the Good Transboundary Water Governance Matrix. While the language is in many ways subtle or abstract, the meaning is still perceptible and 
recognisable. Considering in particular that this analysis is based on a legal perspective, to consider informal approaches to water governance would likely reveal even further linkages to other SDGs. The next step is to address some of the procedural criteria mentioned in the Matrix.

\section{International Cooperation and Governance in the SDGs}

In assessing the SDGs relevance for the future of transboundary water governance, we must examine the cross-cutting goals which address the particular features and challenges of transboundary policy. This brings us to Goal 16 , the purpose of which is to strengthen international cooperation and to develop effective, accountable and transparent institutions at all levels. Considering the somewhat loose and abstract references to the criteria present in the Good Transboundary Water Matrix both in the water specific SDG, and in other sectorial SDGs, it is important to devote close attention to this cross cutting goal.

The targets of SDG 16 are driven by the concept of 'good governance'. They include: promoting the rule of law at the national and international levels and ensuring equal access to justice for all; substantially reducing corruption and bribery in all their forms; and strengthening relevant national institutions, including through international cooperation, for building capacity at all levels (SDG 16). Goal 16 contains five relevant references that align with the Good Transboundary Water Governance Matrix (See Figure 2).

Firstly, the overall vision of SDG 16 is to "Promote peaceful and inclusive societies for sustainable development". This can be translated as a cry for effective international cooperation, which, in the case of transboundary water cooperation, translates into "transboundary cooperation". This must be analysed together with target 6.5 which reads "by 2030 implement integrated water resources management at all levels, including through transboundary cooperation as appropriate." We have already seen how cooperation is promoted in transboundary water governance by following the substantive criteria in the Good Transboundary Water Matrix, with particular attention to the duty 
not to cause significant harm. SDG 16, hence, highlights further the importance of this substantive criterion.

SDG 16 provides a second important reference, present in target 16.3, which reads as follows: "promote the rule of law at the national and international levels, and ensure equal access to justice for all". While some of the substantive and procedural criteria present in the Good Transboundary Water Matrix may fall under the concept of "rule of law", what is more significant is the specific reference in this target to access to justice. This is the fourth procedural criterion included in the Matrix, and is very important in that it provides individuals with the ability to react to breaches of both substantive and procedural obligations in a transboundary water context. The presence of access to justice in a cross cutting SDG like this one implies that for any aspect of sustainable development, and also for transboundary water governance, access to justice is a crucial element.

A third link between SDG 16 and the Matrix comes through target 16.6, which is to "develop effective, accountable and transparent institutions at all levels." This falls under the generic rubric of procedural criteria of the Matrix, which promotes the themes of transparency, predictability, and accountability. Accountability is necessary to build legal precedent, which can be taken into consideration when conflicts may arise. Additionally, transparency and predictability is vital not only for governments, but also in order to engage with the private sector, which has also a role to play in promoting sustainable development.

The fourth reference can be found in target 16.7 which is to "ensure responsive, inclusive, participatory and representative decision-making at all levels". This target is linked with both the first and third elements of procedural criteria enumerated in the Matrix. The first of these being notification and information exchange, which is perpetuated by the idea of "responsive decision making". This is necessary when there are planned measures that are likely to have widespread impact, and may require continual dialogue between the groups involved. The third procedural criterion is public participation, which directly relates to the inclusive, participatory and representative component of the target. This means that not only will decision making be responsive, but it will 
include all affected parties. This is to prevent a multitude of adverse situations where major development decisions could negatively affect water-users who do not have a powerful voice in decision-making, or who are not consulted in the first place. For example, the building of dams could affect downstream riparians who depend on a consistent water flow for agriculture or fisheries. While many issues of this nature can be resolved to the mutual benefit of the parties, there must first be inclusive, participatory and representative decision making.

Finally, the fifth and last reference in SDG 16 that echoes the Matrix comes from target 16.10. The latter provides a further link to the public participation component of the procedural criteria in the Good Transboundary Water Matrix. According to this target there is a need to "ensure public access to information and protect fundamental freedoms, in accordance with national legislation and international agreements." In other words, where international agreements call for "public access to information" this becomes a crucial component for the achievement of sustainable development (UNECE, 1998). There cannot be any public participation if the public does not have access to information, hence the relevance of target 16.10 for transboundary water governance.

In conclusion, SDG 16 can be seen as an important cross cutting goal for sustainable development. In particular, the need for transboundary cooperation, access to justice, transparency and accountability, public participation and public access to information resonates with substantive and procedural criteria in the Good Transboundary Water Matrix (See Figure 2). By reading SDG 6 (the water SDG) and other sectorial SDGs together with SDG 16 transboundary water governance seems to have a presence (albeit not too dominant) in the context of the SDGs.

\section{Conclusion and Looking Ahead to the post-2015 Agenda}

Member States at the Rio+20 Conference recognised the importance of water for sustainable development and the post-2015 development agenda, by clearly emphasizing in The Future We Want that, "water is at the core of sustainable development as it is closely linked to a number of key global challenges" (UN General Assembly, 2012). Building on the efforts already undertaken to reach MDG 
target $7 \mathrm{C}$ on water and sanitation, water will continue to be implicitly central in reaching all of the SDGs. However, during the opening of the fifth session of the intergovernmental negotiations on the Post-2015 Development Agenda, Co-Facilitator Macharia Kamau highlighted that, because the SDGs are interrelated, "we will not be able to pick and choose which goals to implement and which goals not to" (IISD, 2015). This indivisibility of the agenda, due to the integrated nature of the SDGs, indicates that one cannot look at one goal without taking into account its relationship with other goals and targets (Chasek et al, 2015). This is precisely what the analysis of transboundary water governance in the SDGs in this paper has confirmed. Only through a holistic and combined interpretation of all SDGs can transboundary water governance be perceived within the SDG framework. Goal 6 as a standalone goal on water is not enough for transboundary water governance. The substantive and procedural criteria present in the Good Transboundary Water Governance Matrix that we have used to assess the SDGs are only revealed (and even then only to a limited extent) by analysing SDG 6 together with other relevant sectorial SDGs that rely on water and in particular with SDG 16, which calls for further transboundary cooperation, access to justice, transparency and accountability, public participation and public access to information.

As previously stated, the purpose of this paper has been to elucidate the presence of the legal criteria necessary for good water governance within the SDGs. This is not to discount the numerous non-legal methods which are valid in examining water governance as a multidisciplinary field. Legal versus non-legal approaches both have their distinct advantages and disadvantages, and are equally important to understand within the context of global development and the SDGs. For this reason, fully exploring water governance within the SDGs from the perspective of informal strategies is undoubtedly a worthwhile area for further research and study. In conclusion, a cooperative and crosssectorial platform is needed towards achieving good transboundary water governance in both developed and developing countries. The challenge lies in fully understanding that the SDGs cannot be pursued in isolation and that, in the context of water, transboundary water governance deserves the necessary attention. The SDGs are far from perfect, but they do provide a seed with which to start 
improving the future of transboundary water governance. It will be in the implementation stage of the SDGs that countries and all other stakeholders will need to fully invest, as there will not be any effective sustainable development without good transboundary water governance.

\section{REFERENCES}

A New Global Partnership: Eradicate Poverty and Transform Economies Through Sustainable Development (2013) Available at: http://www.post2015hlp.org/wp-content/uploads/2013/05/UN-Report.pdf (Accessed: 30 June 2015)

Blatter J and Ingram H, (2000) 'States, markets and beyond: governance of transboundary water resources' Natural Resources Journal 40(2), pp. 439-473

Bruch, C. (2002) New Public: The Globalization Of Public Participation. Environmental Law Institute.

Bucknall, J, 'Good Governance for Good Water Management', (2006) Environment Matters- The World Bank Group (Annual Review- July 2005- June 2006) <http://siteresources.worldbank.org/INTENVMAT/64199955-1162240805462/21127276/8G oodGovernance.pdf>

Budapest Water Summit Statement, 2013, 'A Sustainable World is a Water Secure World', (2013), Budapest Water Summit Statement: 11 October 2013, Budapest Hungary

Burchi, S. (2012) 'A comparative review of contemporary water resources legislation: trends, developments and an agenda for reform', Water International, 37(6), pp. 613-627. doi: $10.1080 / 02508060.2012 .694800$

Burrel, B. C., Davar, K. and Hughes, R. (2007) ‘A Review of Flood Management Considering the Impacts of Climate Change', Water International, 32(3), pp. 342-359. doi: $10.1080 / 02508060708692215$

Conca, K. (2012) 'The Rise of the Region in Global Environmental Politics' Global Environmental Politics, 12(3), pp. 127-133. 
Cook, C. and Bakker, K, (2012) 'Water security: Debating an emerging paradigm' Global Environmental Change 22(1), pp. 94-102

De Gouvello, B. and Scott, C. A. (2012) 'Has water privatization peaked? The future of public water governance', Water International, 37(2), pp. 87-90. doi: 10.1080/02508060.2012.663614 ENB Report / Summary of the Post-2015 Intergovernmental Negotiations (Follow-Up and Review) / 5th Session | POST2015-IN5 | 18-22 May 2015 | UN Headquarters, New York | IISD Reporting Services (2015) Available at: http://www.iisd.ca/vol32/enb3218e.html (Accessed: 30 June 2015)

Gerlak, AK and others (2011), 'Hydrosolidarity and beyond: can ethics and equity find a place in today's water resource management?' Water International 36(3), pp. 251-265

Grigg, N. S. (2011) 'Water governance: from ideals to effective strategies', Water International, 36(7), pp. 799-811. doi: 10.1080/02508060.2011.617671

Griggs D, Staffod-Smith M, Gaffney O, Rockström J, Öhman MC, Shyamsundar P, Steffen W, Glaser G, Kanie N and Noble I, 'Policy: Sustainable Development Goals for People and Planet', Nature,(2013), 495, (7441), pp. 305-307

Gurría A, 'Water for All: A Matter of Good Governance- The OECD Perspective' (2008) OECD NEWSROOM (Remarks by Angel Gurría, OECD Secretary-General, during the 13th World Water Congress) <http://www.oecd.org/newsroom/waterforallamatterofgoodgovernance-theoecdperspectiv e.htm>

Gurría, A. (2009) 'Sustainably managing water: challenges and responses', Water International, 34(4), pp. 396-401. doi: 10.1080/02508060903377601

IGRAC publishes new Transboundary Aquifers of the World Map - Igrac (no date) Available at: http://www.un-igrac.org/publications/534 (Accessed: 30 June 2015) 
IISD (2014), 'World Water Week Calls for Water Goal in Post-2015 Development Agenda', Stockholm, 5 September 2014, IISD. Available at: <http://nr.iisd.org/news/world-water-week-calls-forwater-goal-in-post-2015-development-agenda/>

International Court of Justice (ICJ), Legality of the Threat or Use of Nuclear Weapons, Advisory Opinion of 8 July 1996

International Decade for Action 'Water for Life' 2005-2015. Focus Areas: Transboundary waters (no date) Available at: http://www.un.org/waterforlifedecade/transboundary_waters.shtml (Accessed: 30 June 2015)

Kaygusuz, K. (2009) 'The Role of Hydropower for Sustainable Energy Development', Energy Sources, Part B: Economics, Planning, and Policy, 4(4), pp. 365-376. doi: $10.1080 / 15567240701756889$

Linton, J. and Brooks, D. B. (2011) 'Governance of transboundary aquifers: new challenges and new opportunities', Water International, 36(5), pp. 606-618. doi: $10.1080 / 02508060.2011 .599312$

McCaffrey, S. C. (2007) The Law of International Watercourses (The Oxford International Law Library). 2nd edn. New York: Oxford University Press, USA

McIntyre, O. (2007). Environmental Protection of International Watercourses under International Law. Aldershot, Ashgate McIntyre, O. (2010). "The Proceduralization and Growing Maturity of International Water Law: Case Concerning Pulp Mills on the River Uruguay (Argentina v. Uruguay)." Journal of Environmental Law 22(3): 475-497

Mirumachi N. (2015), Transboundary Water Politics in the Developing World. Routledge NIDOS, 'What is the Post-2015 Agenda?' (2015) <http://www.nidos.org.uk/post-2015> Norman, E. and Bakker, K. (2014) 'Transboundary Groundwater Governance: An Annotated Bibliography', Water Governance 
Pahl-Wostl, C and others (2013), 'Missing Links in Global Water Governance: a Processes-Oriented Analysis' Ecology and Society 18(2), p. 33-42

Post-2015 Negotiations Begin Discussion on Follow-up and Review read more: http://sd.iisd.org/news/post-2015-negotiations-begin-discussion-on-follow-up-and-review/ (2015) International Institute for Sustainable Development (iisd), 18 May, Report of the Open Working Group on Sustainable Development Goals (2014) Available at: http://www.un.org/ga/search/view_doc.asp?symbol=A/68/970\&Lang=E Review of Targets for the Sustainable Development Goals: The Science Perspective (2015) - ICSU (2015) Available at: http://www.icsu.org/publications/reports-and-reviews/review-oftargets-for-the-sustainable-development-goals-the-science-perspective-2015/review-oftargets-for-the-sustainable-development-goals-the-science-perspective-2015 (Accessed: 30 June 2015)

Sachs, J. D. (2012) “'From Millennium Development Goals to Sustainable Development Goals”', Lancet, 379

Salman, S. M. A. (2007) 'The United Nations Watercourses Convention Ten Years Later: Why Has its Entry into Force Proven Difficult?', Water International, 32(1), pp. 1-15. doi: $10.1080 / 02508060708691962$

Schmidt-Traub, G. and Sachs, J. D. (2015) Financing Sustainable Development: Implementing the SDGs through Effective Investment Strategies and Partnerships. Available at: http://unsdsn.org/wp-content/uploads/2015/04/150408-SDSN-Financing-SustainableDevelopment-Paper.pdf (Accessed: 30 June 2015)

The Critical Role of Water in Achieving the Sustainable Development Goals: Synthesis of Knowledge and Recommendations for Effective Framing, Monitoring, and Capacity Development (2015) Available at: https://sustainabledevelopment.un.org/content/documents/6185Role\%20of\%20Water\%20i n\%20SD\%20Draft\%20Version\%20February\%202015.pdf (Accessed: 30 June 2015) 
The Federal Democratic Republic of Ethiopia, Growth and Transformation Plan (GTP) 2010/11 -

2014/15, Ministry of Finance and Economic Development (MoFED), September 2010, Addis Ababa <http://www.ethiopians.com/Ethiopia GTP 2015.pdf>

The Future We Want: Outcome Document Adopted at Rio +20 (2012) United Nations Conference on Sustainable Development, A/RES/66/288

Tignino, M and Sangbana K (Eds.), Public Participation and Water Resources Management:: Where do We Stand in International Law?, International Conference Proceedings, Geneva, 13 December 2013, UNESCO, 2015,

UN DESA / DPAD / UN System Task Team on the Post-2015 Development Agenda (no date) Available at: $\quad$ http://www.un.org/en/development/desa/policy/untaskteam_undf/process.shtml (Accessed: 30 June 2015)

UN HLP Report, 'A New Global Partnership: Eradicate Poverty and Transform Economies Through Sustainable Development' United Nations' (The Report of the High-Level Panel of Eminent Persons on the Post-2015 Development Agenda, 30 May 2013) <http://www.post2015hlp.org/wp-content/uploads/2013/05/UN-Report.pdf> accessed 30 June 2015.

UN Water, 2014, 'From MDGs to SDGs', (The UN Inter-Agency Mechanism On All Freshwater Related Issues, Including Sanitation) http://www.unwater.org/sdgs/from-mdgs-to-sdgs/en/

UNECE Convention on Access to Information, Public Participation in Decision-making and Access to Justice in Environmental Matters, done at Aarhus, Denmark, on 25 June 1998 UNESCO International Hydrological Programme (2014) Available at:

http://unesdoc.unesco.org/images/0022/002281/228120e.pdf (Accessed: 30 June 2015) UN General Assembly, 2012, The Future We Want: Outcome Document Adopted at Rio +20 (2012) United Nations Conference on Sustainable Development, A/RES/66/288 UN Watercourses Convention User's Guide Fact Sheet Series: Number 5 No Significant Harm Rule (no 
date) Available at: http://www.unwatercoursesconvention.org/documents/UNWC-FactSheet-5-No-Significant-Harm-Rule.pdf (Accessed: 30 June 2015)

United Nations (2008) Draft Articles on the Law of Transboundary Aquifers

United Nations, World Urbanization Prospects (2014) Available at:

http://esa.un.org/unpd/wup/Highlights/WUP2014-Highlights.pdf (Accessed: 30 June 2015)

Young, O. (2008), 'The Architecture of Global Environmental Governance: Bringing Science to Bear on Policy' Global Environmental Politics 8(1), pp. 14-32

Young O. (2003), 'Environmental Governance: The Role of Institutions in Causing and Confronting Environmental Problems' (2003) International Environmental Agreements 3, pp. 377-393

Van Rijswick, M., Edelenbos, J., Hellegers, P., Kok, M. and Kuks, S. (2014) 'Ten building blocks for sustainable water governance: an integrated method to assess the governance of water', Water International, 39(5), pp. 725-742. doi: 10.1080/02508060.2014.951828

Van der Bliek, J., McCornick, P. and Clarke, J. (2014) On Target for People and Planet: Setting and Achieving Water-related Sustainable Development Goals.

Watkins, K. (2015) Leaving no-one behind: an equity agenda for the post- 2015 goals. Available at: http://www.odi.org/sites/odi.org.uk/files/odi-assets/publications-opinion-files/8638.pdf (Accessed: 30 June 2015) 


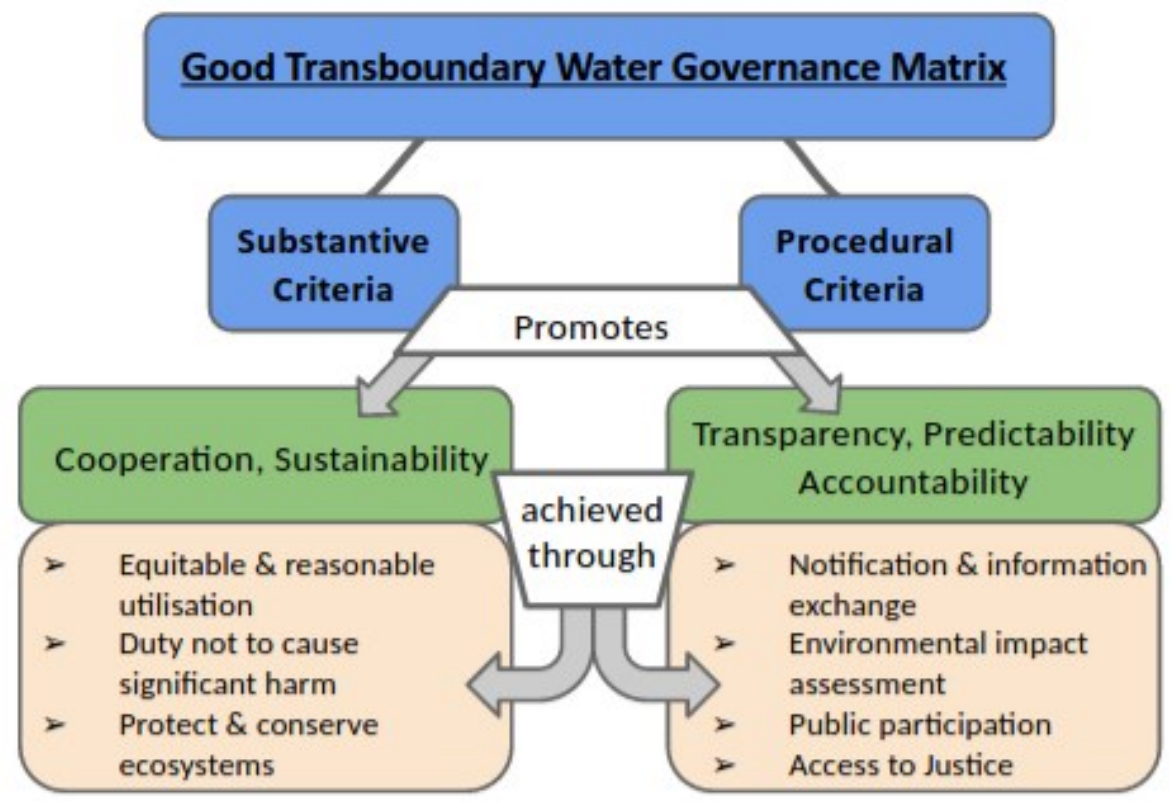

Figure 1

Source: Authors

\section{Cross-cutting SDGs within the Good Transboundary Water Governance Matrix}

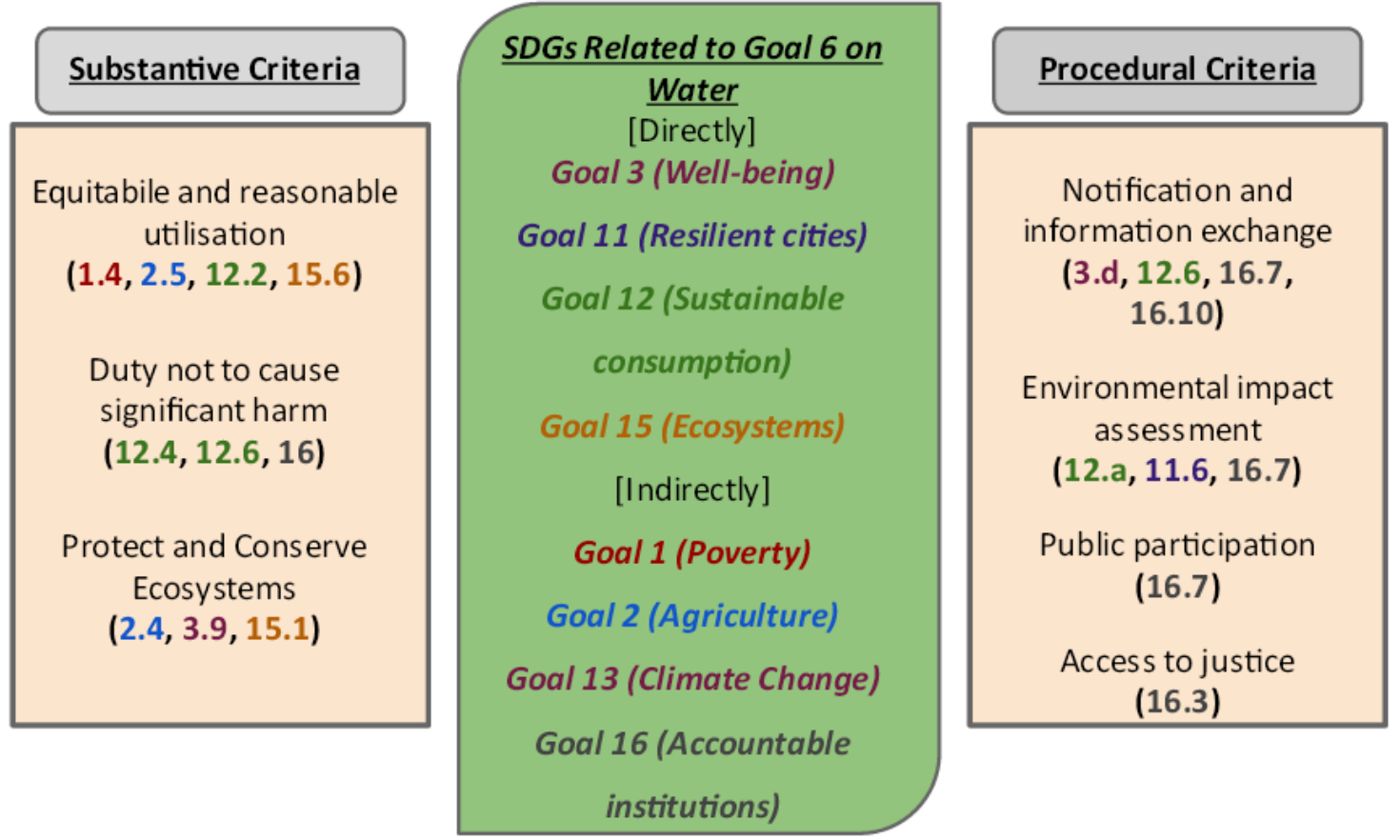

Figure 2

Source: Authors

Note: The linkages made in this figure are based on the targets that specifically mention water governance, or the aforementioned criteria which can be interpreted as having legal implications for water. The numbers on the left and right columns refer to the specific targets under the SDGs listed in the centre column.

\footnotetext{
${ }^{1}$ There are an estimated 276 freshwater lake and river basins worldwide, covering nearly half of the land surface of the Earth. 145 nations have territory which falls within international basins, with 21 nations entirely within
} 
international basins. Governance is crucial for any water source which borders two or more nations. There are currently 13 basins which share up to 5-8 riparian nations, five basins which are shared by 9-11 countries, and the Danube River basin which is shared by 18 different nations (UN Water for Life, 2015). In addition to these basins, 608 transboundary aquifers have been identified around the world, with that number steadily increasing with an almost constant discovery of these bodies since documentation began in 2009 (IGRAC Map, 2014).

2 This was formally adopted by the UNGA in September 2014 as the main basis for integrating the SDGs into the post-2015 development agenda, while recognizing that other inputs will also be considered in the intergovernmental process in 2015 (Chasek et al, 2015). In the run-up to the $70^{\text {th }}$ session of the UNGA in September 2015, a series of eight intergovernmental negotiations on the post-2015 development agenda have been taking place, following the first session convened in January in the UN Headquarters in New York.

${ }^{3}$ The Convention consists of seven parts including: I. Scope, II. General Principles, III. Planned Measures, IV. Protection, Preservation and Management, V. Harmful Conditions and Emergency Situations, VI. Miscellaneous Provisions, and VII. Final Clauses. Each of these parts is then further broken down into articles for a total of 37 articles.

${ }^{4}$ The UNWC, art. 1, did include groundwater in the definition of watercourses, but not in such a way to include all transboundary aquifers. The Draft Articles fill this gap as they do apply to all types of transboundary aquifers and their provisions are geared to groundwater related challenges and problems, while the UNWC is tailored to surface water related issues.

${ }^{5}$ These targets include 3.3 (combat water-borne diseases), 3.9 (reduce deaths and illnesses from water pollution, 11.5, 12.4, 15.1 (ensure conservation, restoration and sustainable use of terrestrial and inland freshwater ecosystems and their services), 15.8 (reduce impact of invasive alien species on water ecosystems).

${ }^{6}$ Globally, more people live in urban areas than in rural areas, with $54 \%$ of the world's population residing in urban areas in 2014. By 2030, the world is projected to have 41 so-called 'mega-cities' with more than 10 million inhabitants (UN DESA, 2014). 